MANOUSOS KAMBOURIS

GEORGE HLIOPOULOS

SPYROS BAKAS

The Association of Historical Studies

KORYVANTES

Athens, Greece

E-mail: mekambouris@yahoo.com
UDC 355.318.1(398)"-03"

$355.422(398) "-03 "$

Original research article

Received: $1^{\text {st }}$ November 2019

Accepted: $15^{\text {th }}$ November 2019

\title{
THE HYPASPIST CORPS: EVOLUTION AND STATUS OF THE ELITE MACEDONIAN INFANTRY UNIT
}

\begin{abstract}
The Hypaspist corps was an elite unit, most probably established by Philip II and inherited by Alexander the Great along with the other components of the Macedonian army. These troops were actively involved in every operation, be it pitched battle or light infantry mission, throughout the Asian campaign and with distinction, thus igniting the interest and curiosity of many scholars. However, in many respects, the nature of the corps remains elusive. The absence of contemporary literature together with the huge time gap to the most militarily literate source available, Arrian's Anabasis of Alexander, combine with the evolving organisation and the restructuring of the Macedonian army under Alexander to shadow the facts. Before being reformed, as Argyraspides' elite line infantry, the Corps, which was different from the two guard formations, fulfilled a double mission, had a wider choice of weaponry and tactics and was organised into three units, while retaining double the strength of the conventional phalanx formations, the Taxeis of sarissa-wielding line infantry. This paper aims to review some of the basic problems of this Corps's identity, highlighting its origins, status, functional deployment, organisation, weaponry and evolution.
\end{abstract}

KEYWORDS: THE HYPASPIST CORPS, PHILIP II, ALEXANDER THE GREAT, MACEDONIAN ARMY.

\section{INTRODUCTION}

The elite Hypaspist corps was a special unit, inherited by Alexander along with the other components of the Macedonian army. The paramount importance of these troops not only during the great battles of Philip and Alexander, but in almost every battle during the campaign of the latter, ignited the interest and curiosity of many scholars. However, the absence of contemporary literature, the huge time gap from the events to our most reliable source, Arrian's Anabasis (approx 500 years), the vague descriptions of Arrian and the frequent reorganisation and restructuring of the Macedo- nian army under Alexander have given rise to extremely diverse opinions. Although the unit was renamed Argyraspides (inferred by combining Arrian VII.11,3 ${ }^{1} \&$ Justin XII.7,4-5 and accepted by modern scholarship, i.e. Anson, 1981) and, most probably, re-oriented towards strictly line infantry operations (retaining an elite status but not its former special-warfare capability status), its functions and internal organisation were rather straightforward before this restructure. A logical answer is attempted herein, to the problem which caused disagreement between Profs Hammond (Ancient

1 Arrian mentions the corps of Argyraspides in VII.11,3 although for the same period he also mentions Hypaspists (VII.8,3) 


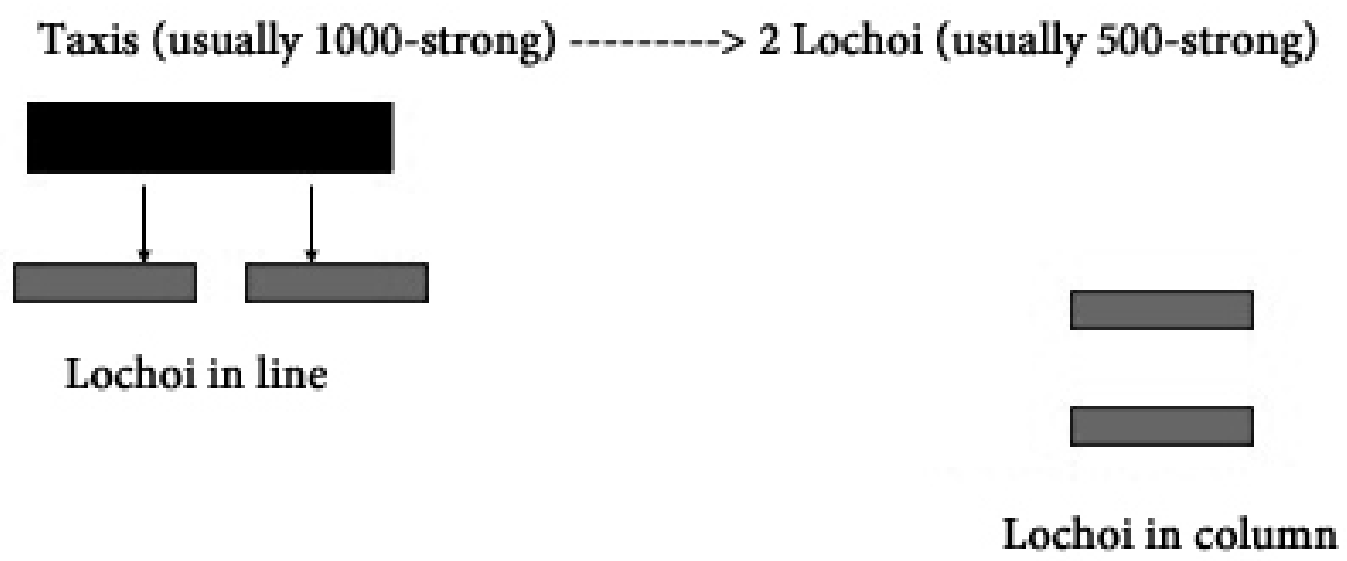

Fig. 1 Greek standard Phalanx unit structure

History Bulletin $11.1 / 1997)$ and Bosworth (Ancient History Bulletin 11.2-3 /1997), i.e. whether there were one or two special infantry units in the Macedonian army, functioning in much the same way as the Napoleonic "Guard" Units. To tackle this problem one is found committed to cope with the problem of the organisation of the Hypaspist corps and of the bodyguard unit(s) in the Macedonian army. The references are, by default, to Arrian's Anabasis Alexandri.

\section{CREATION \& EVOLUTION}

There are some basic things to remember when dealing with the Hypaspists:

First, when Philip ascended to the throne, the unit, or its precursor, the Pezeteroi/Foot-Companions (if Theopompus, F348 is to be trusted) might have been, at first, some 500 strong. It expanded until it was 3,000 strong during the campaign of Alexander ('three Chiliarcies', Arr. An V.23,7). This reference also resolves any issue on the possible organisation of the Corps: Its total of 3,000 was divided to three 1,000 strong units-Chiliarchies (Arr. An III.29,7), each commanded by a Chiliarches (Arr. An I.22,7), ${ }^{2}$ unlike the 1,500

2 Addeus was his name and is mentioned as a casualty, along with the toxarches-leader of the archers. Arrian here makes a careful distinction. Usually he speaks of "archers' chiliarch", since they numbered one chiliarchy but in here strong Taxeis of the Foot-Companions.

Secondly, the name of the unit means "shield-bearers" and in such capacity they should be associated (loosely?) with the Companion cavalry, at the beginning of Philip's reign, just 600 strong (Diod. XVI.4, 3), probably one 100-man Ila from each conscription territory of Lower Macedon. Before detached from the Companions and reformed as a Corps per se, the Hypaspists might well have been embedded in the cavalry, and followed the cavalrymen, carrying the heavy hoplite shield (aspis) of the Companions. Not only had this been a practice well-followed by southern Greek hoplite and cavalry troops, who had squires called Hypaspists (Xen. An IV.2,20), but a task force composed of Companions and Bodyguards (most probably Royal Bodyguards) were specifically ordered by Alexander in one instance to "take on their shields, half of them dismount and charge on foot mixed with the other, mounted half" (Arr. An I.6,5). This means that they had shields (for cases where they had to fight on foot, i.e. sieges), which were not carried when

he changes the term to distinguish from another chiliarch. Since, for the light troops, like javelineers (mostly allied Greeks and Thracians) he refers to Hegemons, and the term chiliarchy is used only for Macedonian army proper units and for the archers, which were a mix of Macedonian and non-Macedonian - at the beginning Cretan - ones (IV. $24,10)$, we should rather conclude that Addeus was a chiliarch of the Hypaspists. 

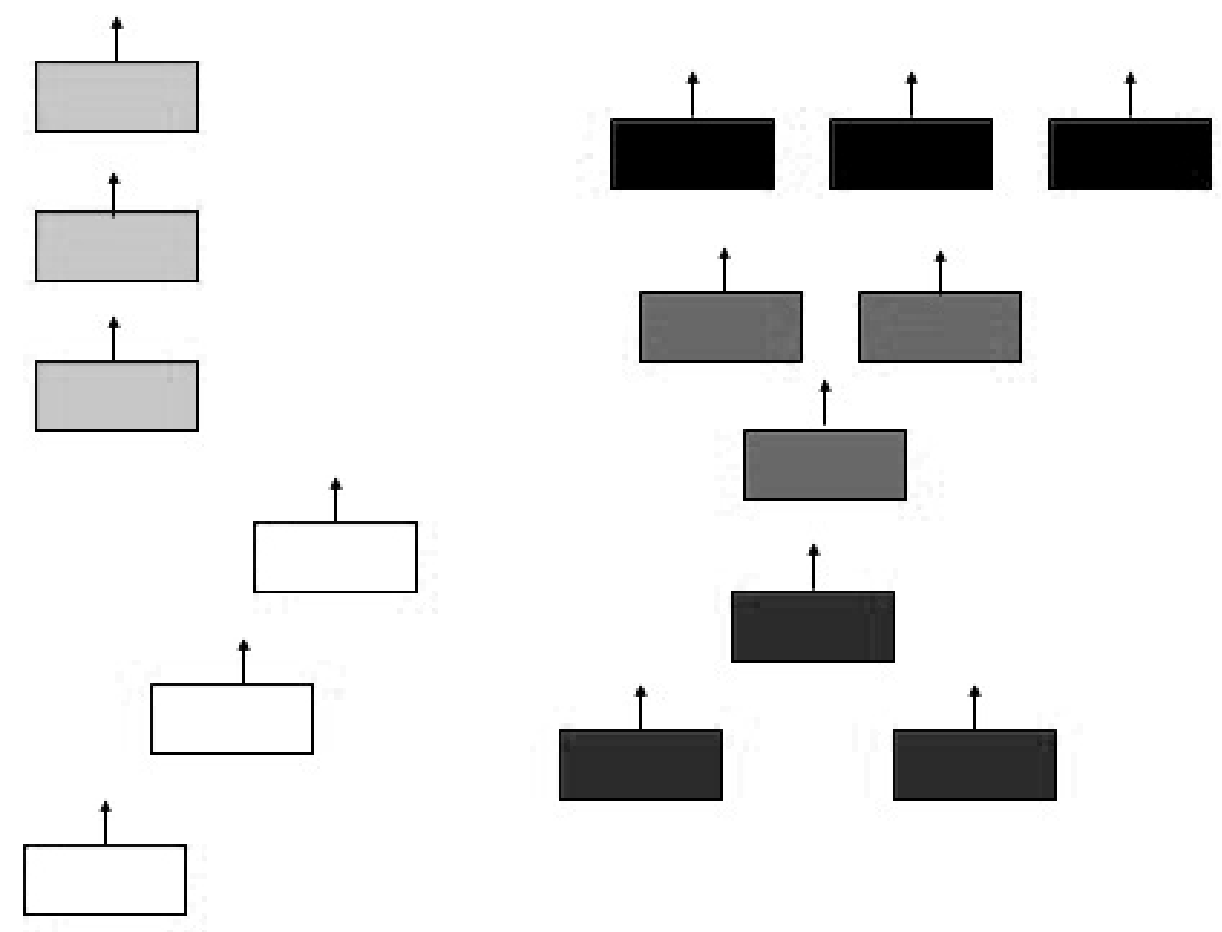

Fig. 2 Possible tactical deployment of the Macedonian foot-companion Taxeis

fighting mounted. One cannot refrain from an association with the hoplite-type shield found by Prof. Andronicos in Vergina, which would fulfill well to such a task for its royal owner. Southern Greek cavalrymen also owned shields, as the elite and usually wealthy cavalrymen (i.e. Kimon, Alcibiades the Younger) might be called to serve as hoplites, either ad hoc or on a yearly basis.

The core of the Hypaspists might have once been the followers/ squires of the Companions, following their masters into battle (perhaps in the way of the southern hamippoi) and carrying their shields- at least in forced marches. From this point to their using the shield in battle, when their master has no use for it fighting mounted, the distance is rather short. To further enhance this view, Arrian himself specifically talks about the "Companions' Hypaspists" under Nicanor (Arr. An I.14,2) referring rather to the whole of the corps in Granicus. This corps might well have been a standing army, at least since Philip reorganised it to a special, independent unit (Anson, 1985), very much like the southern Epilektoi, units, which first appeared in Argos in 418 BC (1000-strong, Thucydides V.67) and then spread to many states and confederacies, the best example being the 5,000-strong Arcadian Eparitoi (Xen. Hell. VII.4,22-5 \& 33-4). Diodorus at least twice (Diod XVI.4,3 \& XVI.86,1) uses this term for describing Macedonian Army units understood to be the Hypaspists. Such a relationship could also make their training in hoplite tactics (phalanx and the new, skirmishing and mobile kind of hoplite warfare of the 4th century BC) much more probable and explicable. The hoplite-style warfare ability of the Hypaspists is demonstrated in Alexander's sarcophagus, with both nude (light) and panoply wearing infantry troops with a hoplite shield and phrygian helmet. This fact, along with the multidimensional training inherent to standing Epilektoi units of southern Greece, as repeatedly mentioned by Xenophon in Hellenica, contradicts the opinion of Milns (Milns R.D. 1967 \& 1971) and others (including, but not restricted to Tarn W. W. 1948) that the only difference to the phalanx rank and file was the Esprit-de-corps, recruitment 

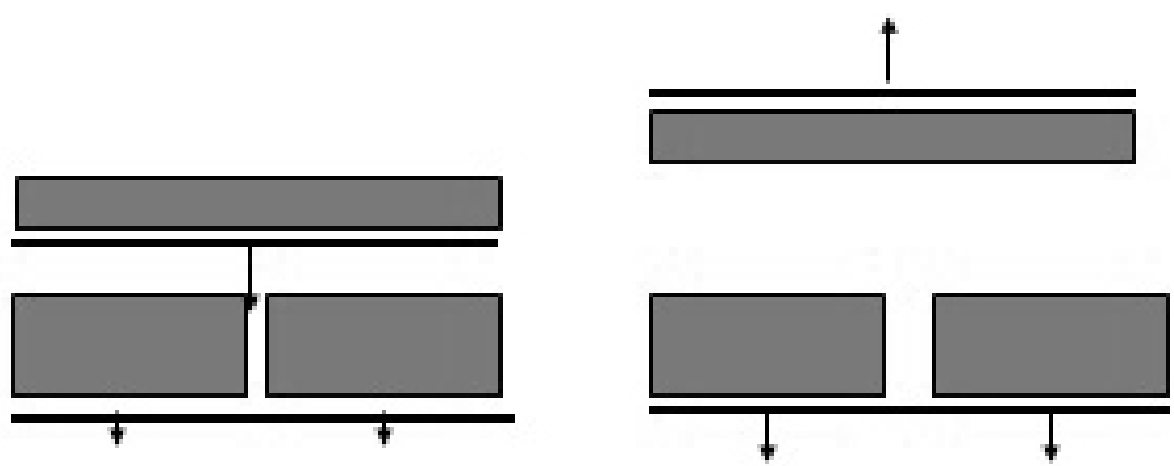

Fig. 3 Double Phalanx Hypaspist Corp deployment in Gaugamela. The second echelon, being in this case the third chiliarchy of the "The Roal Hypaspists", is deployed in standard density, double front, half file depth behind the other two chiliarchies ("The Agema", and the "Rest of the Hypaspists") and may about-turn to face any attack from the rear (“ $\mu \varepsilon \tau \alpha \beta \alpha \lambda o ́ v \tau \omega \nu \tau \eta v \tau \alpha ́ \xi ı v ”$, Arrian Anabasis Alexandri III, 14, 4), possibly using the Macedonian counter-march, thus producing a double phalanx.

and training and discipline. One must not forget the coincidence of size between Hypaspists' Chiliarchies and the southern hoplite units as the Athenian Taxeis, being 1,000-strong. Thus, the Hypaspists, being a standing, professional army, once they had become a Corps, they would have been trained in hoplite warfare (phalanx, mobile and combined operations with cavalry) and in their state-standard sarissa-armed phalanx, fighting as such at least in Hydaspes (Arr. An V.12,2).

During Alexander's reign, we know of a 3,000 strong corps (Arr. An V.23,7). One may suppose that the first step would have been from the first 500 to 1,000 and then to 3,000 in one or two successive steps. After all, during this time, the Companion strength was 2,000 (accounting for the Royal Squadron-maybe 300-strong- the six first-line squadrons of the campaign and the second-line squadrons left to Antipater, each at 150 cavalrymen $^{3}$ ), from the original 600 in Erigon Valley in $358 \mathrm{BC}$, a $350 \%$ increase.

Thirdly, during Alexander's campaign we hear of missions assigned to detachments of 500 and 1,000 Hypaspists (Arr. An III.29,7), which are, logically, whole units of the corps. This binary organisation differs from the foot-companion Taxeis,

3 In II. 9,4 Arrian specifies 300 cavalrymen as a precaution in Issus, for a Persian force lurking in the hills, whereas a little earlier he names two ilai of the companion cavalry being tasked with this, which leads to each squadron-ile being 300:2 =150 strong.
1,500 strong each and consisting of three 512-troop units or six 256-troop Syntagmata (the term for the latter might also have been Lochoi). However, under the tactical level, which denotes the units able to assume independent battlefield missions (Taxis and chiliarchy), the scheme may well have been common. The organisation could well be binary to both line infantry corps (Foot-Companions and Hypaspists) up to 500 men, and from then on the Hypaspists retained a binary organisation all the way to the tactical level (1,000-strong Chiliarchies), whereas the foot-companions changed to a tertiary organisation (1,500-strong Taxis, which allowed for an independent infantry line with two "kerata" ("horns") and one centre, compared to the ancient binary division between left and right, which Polyainos ascribes to Pan, the goat-legged Godlink (Pol. Stratagems I.2,1).

On the other hand, the binary division is much more suitable for the kind of mobile medium infantry missions the Hypaspists usually undertook. Three subunits offer more tactical combinations and flexibility (which is the reason to adopt it in line units) but two subunits are easier to command in mobile operations than three; this posed no problem for the foot-companions, for, despite regularly used for operations on uneven ground, they were primarily infantry of the line and not elite/ special infantry. 


\section{IDENTITY}

To begin with, Philip inaugurated the unit of the Companions' Hypaspists, 500-strong, detaching it from the Companion Cavalry and practically assigning these men under his auspices to an Elite unit, similar to those found in Southern Greece during the 4th Century BC (Epilektoi). Their name, in an army full of esprit-de-corps and special units (the simple line infantry was given the prestigious name "Foot-companions") was associated with their "ante-detachment" status. This same unit must have been originally doubled to 1,000 by Philip (maybe concurrently to the doubling of the Companion cavalry force). When the second Chiliarchy joined, once more doubling the strength, it probably got another name, despite joining the very same Hypaspist Corps. Possibly this name was Basilikoi Hypaspistes (Royal Hypaspists), ${ }^{4}$ to emphasise the difference in origin from the more senior chiliarchy. These men (Royal Hypaspists) did not come from any kind of association with the Companion noble cavalry, which probably meant they were "men of the King" and quite possibly of aristocratic stock- although still from the whole of the realm. The third unit of the corps was the Agema. One cannot be sure about the seniority of the three Chiliarchies, which might well have not been associated directly to their year of establishment; perhaps troopers that excelled in the two first Chiliarchies, were honourably promoted to the Agema. This view contradicts Milns (Milns R.D. 1971), who assigns temporal precedence to the Agema, that is to say that the Agema was the first unit of the Corps. The word of Diodorus (XVI.4,4) for the elite Macedonian infantry in the Battle of Erigon Valley, "Epilektoi" ("picked" or "best"), is an admittedly distant synonym for the Agema, thus being the only real evidence in favour of Milns's view of the Agema preceding other chiliarchies.

4 "Vasilikoi" in Greek may well mean, in different contexts: "royal", "belonging to the king", "kingly", "kinglike", "royalist" or "worthy of a king".
The corps being recruited geographically from the whole of Macedonia, as Theopompus F348 mentions and as the standard practice of Epilektoi units prescribed, contrary to the territory-based recruitment of the foot-companion Taxeis (and Companion Cavalry Ilae), explains the sporadic use of the term "Macedonon Agema", which literally translates to "the best among the Macedonians". ${ }^{5}$ At this point, it is important to notice that Diodorus mentions (XVI.4,4) a picked unit of the Macedonian infantry at the battle of Erigon Valley against Bardylis (most probably in $358 \mathrm{BC}$ ) positioned to the right of the phalanx. This unit, which may or may not have fought as the phalanx did, led by Philip himself, broke the Illyrian line to allow a decisive Companion cavalry charge. The role, the status and the positioning are reminiscent of the Hypaspists and the word Diodorus used (" $\mathrm{Ep}$ ilektoi"- "picked" or "best") is a distant synonym for the Agema and the proper term for equivalent southern standing units. Interestingly, though, in Chaeronia in 338 BC, Philip was identically placed to the right, heading the Hypaspists/ "Epilektoi" (Diod. XVI.86,1) but the actual strength of the unit at the battle of Erigon Valley cannot be determined. It might well have been up to 1,000 , as the ideal army organisation called for a 10,000 heavy infantry force and the Elites to be $1 / 10$ of it. Alternatively, at just onelochos (500-man) might have been the maximum Philip could have afforded at the time, in terms of Elite, professional troops.

\section{FUNCTION AND DEPLOYMENT}

The other important aspect on the subject is the use of the corps in battle. Arrian may refer in different words to the Agema, sometimes just "Agema", other times as "Royal Agema" and even "Macedonon Agema". However, he is rather cautious, not forgeting that he writes half a millennium later, regarding the use of "the rest of the Hypaspists" and the "Royal Hypaspists". He con-

5 Since joining by virtue and enrolled from the whole of Macedon 
fuses these two terms only twice, in Thebes (Arr. An I.8, 3-4) and in Arr. An IV.24,10 (more on these cases to follow). This really points to three, distinctively named Chiliarchies forming the corps. Alternatively, one might think that one 'pentacosiarchia' is the Agema, another is the Royal Hypaspists and the remaining four are 'the rest of the Hypaspists'. The latter view is neither proven nor disproven in the text of Arrian; it is, however, indirectly contradicted by the description of the battle outside Thebes and also in V.13,4, as will be shown later.

The command held by Nicanor, son of Parmenion, who usually commanded the Hypaspists (his brother Philotas commanded the Companions) was reported by Arrian to comprise only two units in some cases, Gaugamela being one of them (another example is Issus, see Arr. An II.8,3). Prof. Bosworth rightly noticed this case, which, however, proves nothing in terms of the total strength of the Corps. When the need arises, even nowadays, a battalion or brigade can still be detached and assigned a separate mission, either independently or under the command of another, higher, echelon. This might well have been the case in both Issus and Gaugamela, and thus the chiliarchies of Hypaspists posted in the battleline under Nicanor might have been part of the total strength of the Corps. However, especially in Gaugamela, contrary to some suggestions, the third chiliarchy, which is not reported in the battle line, should not be assumed missing, nor deployed to guard the major, ditched and palisaded camp, some distance to the rear (III.9,1). This is not where an elite unit would have been left by Alexander during a battle deciding the control of Western Asia.

At the same battle, the first-line heavy infantry of Alexander appears to have comprised only 9,000 Foot- companions plus two or three thousand Hypaspists (III. 11,9). This is far below the maximum, in a battle where Alexander fielded some 47,000 troops (III.12,5). The difference can not only have been due to light infantry, engineering and medical corpses and the Cavalry.
The latter is estimated at 7,000 by Arrian himself (III.12,5); thus leaving some 28,000 of uncommitted troops, a little too many for guards in the camp(s). The balance must be partly in the flank guards, where Arrian explicitly states that light foot (Archers, javelineers, Thracians) were posted (III.12,2-5). Even with this, a large number of troops is still missing.

One possibility emerges from some unclear parts of the text. Arrian speaks (III.11,1) of a " $p h a$ langa amphistomon" 'double -edged phalanx' and "hegemosi ton epitetagmenon" "commanders of the troops at the rear' (Arr. An III.12,1). He also explains the lack of resistance against the Persian cavalry onslaught in the Macedonian camp as being due to the fact that nobody there expected the enemy cavalry to breach the 'double phalanx' (Arr. An III.14,5). The above should lead to the conclusion that there was indeed a second line of heavy infantry, exactly behind the first line (Macedonian phalanx). This second line must have been distributed to commands, each shadowing a Taxis of foot-companions and covering equal space as the foot-companion Taxis to which it was attached. It was to follow the movements of the front command, so a delay of one Taxis, that of Simmias, would cause a breach in both the lines (Arr. An III.14,4-6) but at a distance from its rear. This distance permitted, as Alexander had ordered - and as actually happened - the uncommitted second line units to about-face and cope with any danger at the army's rear (Arr. An III.12,1 and III.14,6) while at the same time the front line units (Taxeis of foot-companions) were engaging, uninterrupted, the Persian line frontally (Arr. An III.14,3). This scheme is somewhat reminiscent of the different Roman maniples of a cohort, although in the case of Gaugamela the rear units were not organically associated with the front units: the arrangement was ad hoc.

The second solution is that the phalanx Taxeis turned a part of their strength to meet the evolving threat. The very popular thought, that they aboutfaced the rear halves of the files, is outrageous: 
About-facing the men would not create a valid front, as the file was not simply one man behind the other but there was a "polarity" to it, based on virtue, age, armament, experience, etc. Reversing the rear half of each file would disrupt the cohesion of the advancing unit and probably cause confusion, a recipe for defeat, especially if under pressure. It is both impractical and in contrast to the passage, which speaks for rear commanders being tasked to reverse and stand. If, though, a whole unit of each Taxis is stationed to its rear, perhaps in a vic formation (two units at the front echelon and one at the rear echelon) the picture changes. The rear unit has its own commanding officer - Hegemon as specified in the text; clearly subordinate to the General of the Taxis. It can be arranged at a distance, so as not to cause confusion when drilling, and also afford some space in between the two echelons for command, decision-making, communications, but also for back-stepping and evacuating casualties. Such distanced units would easily about-turn to face a flanking opponent and perhaps charge to meet him head-on. In order to cover the same frontage assigned to their preceding echelon, which is the quintessence of the whole idea of the 'double-phalanx', they just have to be drawn to less depth, most probably half. This is enough for a defensive and holding action against a flying enemy force.

If this double line per Taxis is accepted, there is absolutely no problem where to look for the third Hypaspist chiliarchy (the Royal Hypaspists) in Gaugamela. It must have been placed to the right edge of the second line, behind the two chiliarchies posted in the first echelon.

Behind the phalanx, there were squires (grooms), ${ }^{6}$ who "arrested" the Persian scythed chariots which made their way through the corridors the phalanx opened when faced with their onslaught (Arr. An III.13,6). Needless to say, the

6 Most probably the grooms of the Phalangites and of the Hypaspists; Philip allowed one for every 10 Phalangites, compared to 1:1 for Hoplites in southern armies and 7:1 in some Spartan task forces. This produces a very hefty 9,000-man rear line, initially behind the phalanx and then between the two echelons. division of the rear line to units closely attached and following the Taxeis of the first line permitted the opening of these corridors with excellent efficiency compared to the capabilities offered by a possible unified, "monoblock" command of the rear line. This latter arrangement might have been a common, if not usual, practice during the $4^{\text {th }}$ century, as described by Xenophon for both "The Ten Thousand" and for Agesilaus at the Battle of Sardis, 395 BC (Xen. An VII.3,46 and Xen. Ages I.31 respectively).

Moreover, in that same part (Arr. An III.13,6) Arrian specifically mentions the Royal Hypaspists along with the grooms arresting the chariots that had passed harmlessly through the phalanx to its rear. So, Royal Hypaspists (not Companions Hypaspists, or the Agema) were in such a position as to operate at the rear of the phalanx. It is intriguing to think that Nicanor's immediate command comprised all three Hypaspists' Chiliarchies, in a very modern two in front, one, to the rear arrangement. The inconsistency in numbers (two units in the front, one to the rear) could well have been remedied by the rear unit being deployed in half the front one's depth, thus equalising the front of both echelons of a division. This concept, if followed for all the heavy infantry deployment, meant a 2:1 distribution of manpower in favour of the first line; this adds to the ferocity of the charge as mentioned. This would lead to an 8,000 strong first line (two Chiliarchies of Hypaspists and the 1,000 men of each of the six Taxeis of foot-companions) and a 4,000 -strong second line (half of the first), resulting in a 12,000 strong infantry.

Another issue is the battle outside Thebes. Prof. Bosworth's view, that the second Macedonian infantry line might have been the whole (of the rest) of the phalanx is not necessarily valid. Indeed, the engagement of two Taxeis left four more uncommitted. However, the breach to the Theban defensive position cannot have allowed for more than a two Taxeis deployment, otherwise the remaining Taxeis would have taken the Theban flanks from the very beginning, not to men- 
tion the Macedonian cavalry who would have doe the same. The very nature and positioning of the stockade and trench must have hampered deployment, even when breached, so Alexander should not have been able to deploy his line infantry to this width, even outside the trenches. He must have been restricted to a similar number of men, at least if he was to use them to some effect. The two Taxeis probably numbered 2,000 men altogether, if fully mobilised. The two mentioned Chiliarchies, (Royal) Hypaspists and Agema numbered 2,000 . The latter, with double-width spaces between successive files allowed the men of the front line, who were repulsed by the Thebans, to retreat, catch their breath and regroup by passing through such lanes to the rear. This retreat through the second line could explain Diodorus' account (Diod. XVII.11,1-12,4) of the Thebans receiving the attacks of two Macedonian lines before breaking with the attack of the third. One can imagine that the third part of the army (Diod. XVII.11,1) would comprise the rest of the Taxeis of foot-companions and the rest of Hypaspists (one Chiliarchy), that is if indeed the second line comprised only two Chiliarchies; a substantial' number of troops were deployed to other parts of the circuit and assaulted it as the battle at the breach intensified.

\section{ORGANISATION}

The problem is that this seems to be one of the very few (just two) parts where Arrian indiscriminately uses the terms "Royal Hypaspists" and "Hypaspists". In I.8,3 he mentions the latter being posted next to the Agema, while in I.8,4, just a few lines later, he mentions that the fleeing Foot-Companions where received by the Agema and the Royal Hypaspists. However, this is rather vague; the reference could very well mean that in this case all three Chiliarchies of the Hypaspist Corps were lined up, with the Agema in the middle. Due to ground factors, the retreating Foot-Companions might well have retired through two of the three lined up Hypaspist Chiliarchies.

The other section where "Royal Hypaspists" is supposedly used sensu lato and thought to refer to the whole Hypaspist Corps, is IV.24,10. Here, Arrian says that a third of the Royal Hypaspists were dispatched to a certain task. This is widely thought to mean a third of the Hypaspist corps, i.e. 1,000 Hypaspists (Milns R. D. 1971). Things might be a little more complicated. If this had been the case, it would have been prudent to dispatch a whole unit and not a collection of individual troopers, or small units. In such case, however, Arrian would have clearly stated that a Chiliarchy of the Hypaspists was assigned a task; as he did in III.29,7. So, it may well be that Arrian is very accurate in his terminology in this case and does not refer to a mission undertaken by a whole Chiliarchy of the Hypaspist Corps (1,000 men out of 3,000 ), but to a detachment of one specific Chiliarchy: the one-third of the Royal Hypaspists (300 men out of 1,000).

The passage about Hydaspes (Arr. An V.13,4) that is mentioned by Prof. Bosworth simply verifies this opinion. All three Chiliarchies are mentioned one by one, and we also learn of another commander, Seleucus. Could he have been in charge of the Royal Hypaspists in Gaugamela as well or is he replacing Nicanor as commander of the Corps? This passage speaks about Royal Hypaspists under Seleucus, the Agema and then the rest of the Hypaspists being deployed according to the order of the day. This implies more than one separately commanded units apart from the two already mentioned. So, he could well be speaking about the 500-strong units of the corps, of which there were six (coupled into three Chiliarchies). This is the only part of Arrian's account that could be taken to imply that the Royal Hypapsists and Agema were actually 500-strong units of the Hypaspist Corps and not full Chiliarchies, as believed by Berve I, 127 (1926).

This leaves some other questions open regarding Arrian's style. Prof. Bosworth rightly points out that there is only one mention of the "Mace- 
donon Agema" and numerous of the "Agema" and "Hypaspists' Agema", and the "Royal Agema". The same is true with the third Chiliarchy of the Hypaspists and the Corps. In Granicus there is mention of "Companions' Hypaspists" (I.14,2), and from then on usually just "Hypaspists". As far as the Agema is concerned, it could be considered that by clearly mentioning "Hypaspists' Agema", Arrian is reminding his reader that this Agema unit is part of the Hypaspist corps. ${ }^{7}$

However, from this point on, there are two distinct possibilities:

The full name of the Agema was indeed the "Macedonon Agema" and once mentioned, to inform the reader of the full name, Arrian shifts to the simpler version of "Agema", from time to time reminding that it was a unit of the Hypaspist Corps.

The name of the unit is simply the Agema. This leads Arrian to define, just once, that it is a Macedonian unit (and most probably recruited from the whole of the realm) to prevent any confusion with the Agema of the Spartan army (which must have been the prototype) or of any other Greek army which had such a unit.

As far as the "Companions' Hypaspists" are concerned, the solution might well be a similar one. Arrian mentions this name just once because he does not know which of the following might be correct:

The first alternative: the whole Hypaspist Corps is called "Hypaspists" and comprise three Chiliarchies: the Agema, the Royal Hypaspists and the Companions' Hypaspists", the latter being the first unit of the corps to have been formed.

The second alternative: the originally formed unit was the Companions' Hypaspists" (Arrian attests to this in I.14,2) but when the Corps expanded, this title described the whole corps, the original unit being then called simply the Hypaspists

7 It could also be very bold to propose that the "Agema" proper was a chiliarchy and comprised two pentacosiarchies, the "Makedonon Agema" and the "Royal Agema". This would explain the plural of "Agemata" outside Thebes in I. 8,3 . and comprising only a third of the corps, along with the Royal Hypaspists and the Agema. This Chiliarchy, the Hypaspists (former Companions' Hypaspists), Arrian refers to as the rest of the Hypaspists for lack of a suitable and accurate characterisation or epithet.

Regarding the polymorphism in Arrian's language, which is a central argument of Prof. Bosworth's account of the "guard units" of the Macedonian army, one could remark that he is the author of a tactical treatise ("The Art of Tactics"), where terms are used strictly and systematically. In other words, Arrian might be expected to use such linguistic behaviour in every part of his narrative BUT the military terminology. This does not mean he is always accurate. Comparing and creating consensus from more than one source (he has at least two major ones) is by no means an easy task, resulting in his vague comprehension in many passages; at the crossing of the Hydaspes, for example, he places half of the Hypaspists in the same small triakondoros vessel with Alexan$\operatorname{der}(\mathrm{V} .13,1)$.

\section{(ROYAL) BODYGUARDS}

Prof. Bosworth's view of the Somatophylakes ('bodyguards') and the Vasilikoi Somatophylakes ('royal bodyguards') being one and the same is also ill-substantiated. There were only seven Bodyguards and an eighth was added as an honour for saving Alexander's life in the citadel of Malli; this was Peucestas (Arr. An VI.28.3). Bosworth's view of them belonging to the Companions is not contested here, but Peucestas must,,or might, have been a Hypaspist. ${ }^{8}$ On the other hand, the Royal Bodyguard is stated to have followed

8 In I. 11,8, Arrian says that the sacred arms taken from Troy were borne by the Hypaspists before Alexander in battles and, in VI.28, 3-4, Peucestas is supposed to have assisted Alexander at the Malli citadel bearing the shield taken from Troy, which makes him very probably a Hypaspist. Moreover, in VI.9,4, Arrian specifically states that the Hypaspists were following Alexander in his assault to the walls and, furthermore, Diodorus, in XVII.99,4, calls Peucestas a Hypaspist. 
Alexander himself on a special mission, against the Uxians, along with some Hypaspists and "8,000 of the other infantry" (Arr. An III.17,2). This means that the Royal Bodyguard was a unit by itself, for there would have been no reason for Arrian to enumerate just seven bodyguards along with other units (Hypaspists and other types of infantry). This Royal Bodyguard must have been some hundred strong and been able to assume battlefield assignments, much like the Guard units of the Napoleonic Era. Moreover, in IV.30, 3, Arrian states that Alexander took the "Bodyguards and Hypaspists up to 700" to occupy the a position, called Rock, abandoned by its defenders. This readily reads as a unit of Hypaspists (500, since their major unit was the "thousand"- chiliarchy) and the Bodyguards $(700-500=200)$. However, its primary function would have been, understandably and again like European Renaissance Guard units, to attend to a variety of duties, such as the guarding of the palace in peacetime or whenever the king was in residence, as well as secret police/ military police functions. It is very tempting, almost compelling, to identify them with the Royal pages, an institution possibly copied from the Persians (as proposed by Keinast, 1973), and described as such by Xenophon (Xen. An I.9,3-4). Arrian mentions the pages as bodyguards in the chapter regarding their conspiracy (Arr. An IV.13), and the duties that he details to them fall squarely into the jurisdiction of a bodyguard. Moreover, when Diodoros says that Hephaistion was wounded at Gaugamela while leading the Bodyguards (Diod XVII.61,3), he most probably means the Royal Bodyguards, who followed, as always, the king and, in this instance, fought on horseback, as he did; when the king fought on foot (IV.30,3), so did they. This also explains the elusive unit of "the other friends" under Philotas in his description of the battle order (Diod XVII.57,1): this unit is not named but it followed the Royal Ile under Cleitus the Black and preceded the other seven Companion Hipparchies (the latter name is most probably anachronistic).
The reason for inconsistent referencing in Arrian (Royal Bodyguard vs Royal page) may be a drastic change in Alexander's court. Alexander loved changing things and maintaining a dynamic condition to his establishment, in order to allow adaptations and also to negate the establishment of local focal points of personal power and might, which was a difficult job in the traditionalist Macedonian Army. Thus, after the conspiracy the Pages might have been renamed, as after Philotas' conspiracy the Companion Cavalry was divided to two under Cleitus and Hephestion (Arr. An III.27,4). Unfortunately, as the Royal Bodyguard is mentioned both before (Arr. An III.17,2) and after (Arr. An IV.30,3) the Conspiracy of the Pages (Arr. An IV.13), this idea might have to be reconsidered; Arrian's change of the source he followed, whereupon he might have opted to follow the terminology of each, might be the true, although much less appealing, reason. Another possibility is the Royal Bodyguard to have been the final stage and, thus, the culmination of Page duty. Royal Bodyguards were Royal Pages, but not all Pages were in the Royal Bodyguard at the same time. Moreover, it is very probable that the Pages, after graduating, joined the Royal Hypaspists if inclined to a military career. Heckel (1986) supports the transition from the Royal Bodyguard to the Agema, (for no evident reason but the notion that the Agema and the Royal Hypaspists were one and the same), or the Companion Cavalry as a territorial army if joining their families back in their estates or if assuming government positions. It is entirely possible that the Companions, after the first generation which were handpicked and invited by Philip to expand the Corps, were admitted after service as Royal Hypaspists, to solidify their loyalty to the head of state and familiarise themselves with infantry support and warfare, which they would be required to depend on or to command. It is very tempting to identify Aretes, the squire who passed his spear (xyston) to Alexander in Granicus (Arr. An I.15,6), and obviously a Royal Page given that squiring to the King was 
among their duties (Arr. An IV.13,1), with Aretes the leader of the mounted scouts in Gaugamela, (Arr. An III.12,3) thus showing the professional potential of the Royal Pages.

\section{INNOVATING AND CONSERVING}

A pivotal part in this study is the idea of Macedonian main units being of a tertiary structure. The Hypasist Corps included three units. Is this the case with the Phalanx and the Companion Cavalry? The Macedonian army followed, in the most part, the southern Greek golden rule of a 1: 10 ratio between cavalry and infantry and special/ standing units and levies. Thus, the Taxeis must have been 10 times larger than the Ilae, following the same structure, the Hypaspists must have been 10 times the strength of the Royal Ila and the cavalry must have been equal in strength to the Hypaspists. Although this is difficult to prove, as half the army stayed in Macedon with Antipater, the basic idea remains valid: it is no coincidence that in Gordium (Arr. An I.29.4) the ratio of Macedonian cavalry and infantry reinforcements was $1: 10$. The notion of the Ilae being 150-strong comes from the battle of Issus in II.9.4 and II.9.3. Prior to that, both in Pelium (Arr. An I.6.1) and in western Asia Minor, after Granicus (Arr. An I.18.1), a figure of 200 for detachments of Companions is reported. This cannot accord with a 150 -strong Ilae; they are obviously 100-strong and of a binary structure as with standard Greek practice. The key are the reinforcements arriving at Gordium (Arr. An I.29.4): the 300 new cavalry would have been sufficient for one more 50-horse sub-unit for each of the six Companion Ilae, and the same would have been true for the 3,000 fresh phalanx troops: one more 500-strong subunit for each of the six Taxeis. It is at this point, before the obvious showdown with Darius and the imperial Persian army that Alexander changed the structure of his army, to enhance its tactical flexibility; he would do so once more after Gaugame- la, again after receiving massive reinforcements under Amyntas in Susa (Arrian III.16,10; Curtius V.1.40), returning to a binary structure, better suited to mountain and unorthodox warfare. On this occasion it would remain thus to the end of the Macedonian state, almost two centuries later.

For the cavalry, Arrian is resolute; Companion Ilae were augmented from 150 to 200 cavalrymen and divided into two Lochoi (Arr. An III.6,11), supposedly 100-strong; for this, the 500 cavalry brought by Amyntas (Curt V.1,41) were more than enough. For the Infantry, a degree of conjecture is required: the existing six Taxeis were augmented from 1,500 to 2,000 by one more 500-man Lochos (Curt V.2,3) and divided into two Chiliarchies each; this transformation required at least 3,000 phalangites, the product of the fourth Lochos of 500 by the six pre-existing Taxeis. With the Taxiarchs being automatically assigned one of the two Chiliarchies of their respective Taxis, six new commanders, Chiliarches, were required, who were elected as described in Curt V.2,3-5. Another two commanders were needed for the command of the two chiliarchies of the newly established seventh Taxis; its establishment required another 2,000 troops, bringing the total to 5,000 phalangites, whereas 6,000 had been brought by Amyntas (Curt V.1,40).

Arheologija i prirodne nauke (Archaeology and Science) is an Open Access Journal. All articles can be downloaded free of charge and used in accordance with the licence Creative Commons - Attribution-NonCommercial-NoDerivs 3.0 Serbia (https://creativecommons.org/licenses/by$\mathrm{nc}-\mathrm{nd} / 3.0 / \mathrm{rs} /$.

Časopis Arheologija i prirodne nauke je dostupan u režimu otvorenog pristupa. Članci objavljeni u časopisu mogu se besplatno preuzeti sa sajta i koristiti u skladu sa licencom Creative Commons - Autorstvo-Nekomercijalno-Bez prerada 3.0 Srbija (https://creativecommons.org/licenses/by$\mathrm{nc}-\mathrm{nd} / 3.0 / \mathrm{rs} /$. 


\section{BIBLIOGRAPHY}

$\underline{\text { Ancient }}$

Arrian: Anabasis of Alexander

Arrian: The Art of Tactics

Diodorus Sicilus: Library of History

Herodotus: Muses

Justin: Epitome of the Philippic History of Pompeius Trogus

Polyaenus: Stratagems

Quintus Curtius Rufus: Historiae Alexandri Mag$n i$

Thucidydes: Histories

Xenophon: Anabasis of Cyrus

Xenophon: Agesilaus

Xenophon: Hellenica

\section{Contemporary}

Anson, E. M. 1981

Alexander's Hypaspists and the Argyraspids, Historia: Zeitschrift für Alte Geschichte, Bd. 30, H. 1: 117-120.

\section{Anson, E. M. 1985}

The Hypaspists: Macedonia's Professional Citizen-Soldiers, Historia: Zeitschrift für Alte Geschichte, Bd. 34, H. 2: 246-248.

\section{Berve, H. 1926}

Das Alexanderreich auf prosopographisch, Gerrundlage 1926, 2 vol.

\section{Heckel, W. 1986}

"Somatophylakia": A Macedonian "Cursus Honorum”, Phoenix, Vol. 40, No. 3: 279-294.
Milns, R. D. 1967 Philip II and the Hypaspists, Historia: Zeitschrift für Alte Geschichte, Bd. 16, H. 4: 509-512.

Milns, R. D. 1971

The Hypaspists of Alexander III: Some Problems, Historia: Zeitschrift für Alte Geschichte, Bd. 20, H. 2/3: 186-195.

Tarn, W.W. 1948

Alexander the Great, Vol II, Cambridge: Cambridge University Press.

\section{REZIME \\ KORPUS HIPASPISTA: EVOLUCIJA I STATUS MAKEDONSKIH ELITNIH PEŠADIJSKIH JEDINICA}

\section{KLJUČNE REČI: KORPUS HIPASPISTA, FILIP II, ALEKSANDAR VELIKI, MAKEDONSKA VO- JSKA.}

Korpus Hipaspista je bio elitna jedinica, koju je verovatno osnovao Filip II, a nasledio ga je Aleksandar Veliki, zajedno sa ostalim komponentama makedonske vojske. Te su trupe bile aktivno uključene u svaku ratnu operaciju, bilo da se radi o velikoj bitci ili nekoj manjoj pešadijskoj misiji tokom velikih ratnih pohoda na azijskom kontinentu, probudivši interes mnogih naučnika koji su se bavili ovom temom da bliže odrede njihovu ulogu i značaj. Međutim, u mnogim aspektima, priroda korpusa još uvek nije dovoljno rasvetljena. Ovaj rad je pokušao da postavi neke osnovne probleme karakatera ovih jedinica, ističući njeno poreklo, status, funkcionalno raspoređivanje, organizaciju, oružje i evoluciju.

Kienast, D. 1973

Philip II, von Makedonien und das Reich der Achaimeniden: Munich. 